\title{
Visualization of Indonesian culture as backgrounds in Pocari Sweat Ads "Bintang SMA"
}

\author{
A. Syafikarani, T.R. Deanda \& G.P. Nabila \\ Telkom University, Bandung, Indonesia
}

\begin{abstract}
COVID-19 made the advertising business drop forcing shifts in its media strategy toward digital media. One of them is by using animation media, such as the Pocari Sweat animation ad "Bintang SMA", where the ad also carries some cultural values. This research studies how Indonesian culture is represented in the animated background of the Pocari Sweat animation ad "Bintang SMA". The data obtained from case studies, documentation, and distributing questionnaires methods were analyzed using the theory of cultural movement and local culture. From this study, it is known that the Indonesian culture is represented in Balinese and Jakarta culture through location, architecture, and property settings. The results of this research can be used as input for those involved in the world of advertising, especially in compiling an animated media advertisement by raising cultural elements as an advertising solution in the middle of the pandemic.
\end{abstract}

Keywords: advertising, animation, Indonesian culture, Japanese visual style, COVID-19

\section{INTRODUCTION}

The COVID-19 pandemic has triggered a decline in activity in various fields, including in the world of advertising. As stated by the Association of Indonesian Advertising Companies (P3I), the advertising business has decreased by $35 \%$ from March to April in the last two months. This requires creative industry players to innovate in making advertising strategies and adjusting to the current situation. According to Janoe Arijanto, chairman of P3I, the advertising industry is currently trying to encourage "goodvertising", which is a form of communication that is more empathetic, relevant, and provides solutions to the complexities experienced by the public (Jawa Pos 2020).

This is because the pandemic is expanding and the work from home policy has also increased as has watching television and internet consumption. Therefore, brands are starting to shift their media strategy toward digital by using simple and efficient material without reducing their advertising goals and intentions. One of the efforts that can be made by a brand in advertising with simple and efficient media is using animation media. By switching to using animation media, it can be a substitute for shooting commercials that are done directly at several shooting locations. Therefore, this can be used as an alternative to keep health protocols running during a pandemic and remain productive to increase the creative economy. This is also supported by the results of the questionnaire that showed that $97 \%$ of respondents stated that animated ads were effective in delivering product promotions and $97.3 \%$ also stated that animated advertisements could be used as an alternative choice for an advertising solution during the COVID-19 pandemic. Therefore, in this study, researchers introduced a case study on the animated advertisement of the Pocari Sweat "Bintang SMA", where the advertisement carried several cultural values which were met with the right momentum, namely the limited production of advertisements due to the COVID-19 pandemic and taking advantage of the development of the Makoto illustration style trend, who is very popular in the world of animation. So, the creative industry movement is not just a fleeting trend, not just a lifestyle, but a continuous opportunity. This also fits perfectly with the concept of goodvertising that is being developed. In previous research conducted by the Munggaran, entitled "The Meaning 
of Cumulonimbus Clouds as Background Art in the Animated Film The Girl Who Leapt Through Time by Mamoru Hosoda", it is known that the background has an important role and it contains a representation of culture (Munggaran 2019).

This paper stated that natural objects, namely clouds in Japanese animation, contain certain meanings in Japanese culture. There it can be seen that the background has a role that is no less important than the presence of characters. However, there has been no further research that discusses the representation of Indonesian culture on an animated background, therefore this study intends to study how Indonesian culture is represented in the animated background of the Pocari Sweat advertisement "Bintang SMA". So that the results of this study can be used as input for parties involved in the world of advertising, especially in compiling an animated media advertisement by raising cultural elements as an advertising solution amid the COVID-19 pandemic.

\section{RESEARCH METHOD}

This research is included in the qualitative paradigm. Research was conducted by looking at specific patterns is then developed into more general patterns and aims to generate hypotheses from field research. This is supported by Judistira K. Garna's statement which states that a qualitative approach is characterized by the aim of the researcher who seeks to understand symptoms in such a way that does not require quantification, or because these symptoms are not possible to measure quickly (Afdjani 2010). The method used is a case study on advertisements that are in accordance with the research objectives, namely the animated ad Pocari Sweat "Bintang SMA". This is because the ad has succeeded in attracting the attention of the audience. On YouTube, the advertisement has been watched more than 14,714,720 times. Besides that, the Japanese anime-style illustration style wrapped with the diversity of Indonesian culture makes the advertisement have its own charm. Data collection techniques used are field studies to obtain primary data obtained through documentation and collecting animated media advertisements in image format derived from recorded advertisements on YouTube media. As well as distributing questionnaires online, to obtain data on audience perceptions of the animated Pocari Sweat "Bintang SMA" ad. From the distribution of the questionnaire obtained data of 303 respondents, with a dominant age between 15-20 years, who are in junior high and high school. In addition, a literature study was also carried out to obtain secondary data through books, journals, articles, and some literature on internet sites. The data that has been obtained is analyzed using the visual discourse analysis method, a method that has a function to find meaning and discourse in a work based on capital such as visual, verbal, and sound (Kress \& Leeuwen 2006). In addition, it is supported by cultural movement theory, which is a theory that explains that a brand is not just designing a logo and developing a narrative but is much more fundamental, namely re-coding it culturally or culturally (Hendroyono 2019).

\section{RESULT AND DISCUSSION}

The 60-second Pocari Sweat animation ad "Bintang SMA" tells the story of two students: Ayu slive in Bali and Reza lives in Jakarta. Both want to achieve their goals by participating in Bintang SMA. This ad is directed by Shinomiya Yoshitoshi, a Japanese animator who is heavily involved in animation production, especially in the case of illustration and background design. Some of the anime that he has worked on are anime by director Makoto Shinkai, such as "Children Who Chase Lost Voices", "The Garden of Words", and "Your Name" (Kusumanto 2019). Therefore, this ad also utilizes the right momentum by carrying the nuances of the Japanese anime style to represent the origin of the Pocari Sweat drink, but still wrapped in the diversity of Indonesian culture as local wisdom where the ad is located. Based on the results of the questionnaire, obtained data showed that the background scenes that stand out in representing Indonesian culture are the statue scene at $74.4 \%$, the Bundaran HI scene at $66.8 \%$, the offering scene at $60.5 \%$, the school gate scene at $58.8 \%$, class atmosphere scenes at $48.8 \%$, kite festival scenes at $33.9 \%$, bus stop 
scenes at $19.9 \%$, and Wisma 46 scenes at $7.6 \%$. Therefore, this research will be divided into three parts, First, the school which consists of the school gate scene and classroom atmosphere. Second, Bali, which consists of a statue sculpture scene, a scene of offerings, and a kite festival scene. Third, Jakarta, which consists of the Bundaran HI, bus stop, and Wisma 46 scenes. After that, each of these parts will be analyzed more deeply based on the location, architecture, and supporting properties because based on the results of the questionnaire, $59.8 \%$ stated that the architecture of these animated advertisements had a majorly contributed to representing Indonesian culture.

\subsection{School}
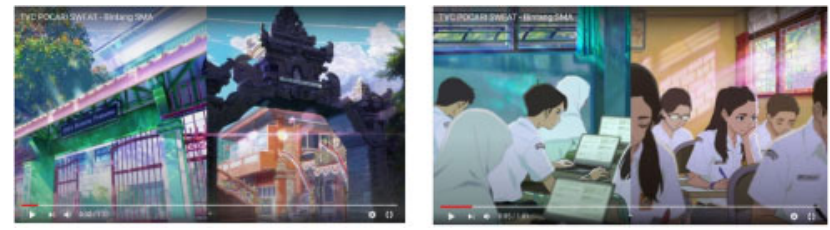

\section{a. Location Settings}

The ad begins with a frame that shows the location setting of a school by displaying two different school gates side by side. In image (1), the background is seen in the form of buildings and gates of Bintang Pratama and Ganesha Denpasar High Schools. The gate as the "face" of a building is used as a sign of place identity (Pattymahu 2016), supported by the placement of scenes in the first frame. In one frame, there are two gate facades with two different identities. On the left side, the gate structure is commonly found in schools in Indonesia. On the right side of the frame, local identity is more focused on Balinese culture, which can be seen from the variety of decorations and archways. In picture (2), the building background is visible and there are windows, curtains, and poster frames. This shows that the background of this frame is in the form of classrooms of Bintang Pratama High School and Denpasar Ganesha High School. This frame shows that at the beginning of the ad the chosen location setting has been explained in this animated advertisement, which shows that modern urban locations are represented through the Bintang Pratama High School. From success comes growth, which is in line with urban conditions that are moving toward modernization. In addition, locations that represent regions can be seen throughout the dominant Ganesha Denpasar High School that use brown as a symbol of simplicity, classics, and tradition. Besides the frames that are displayed in parallel, it also represents that the frame intends to compare two different locations with the same time or condition.

\subsection{Bali}
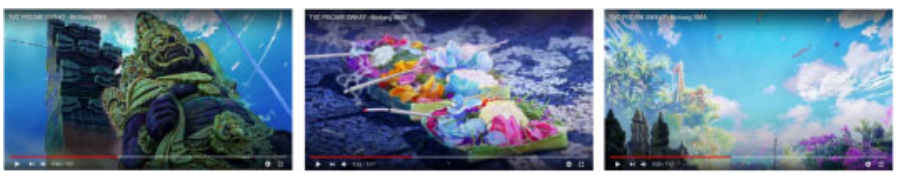

\section{a. Location Settings}

The next frame shows the location setting of Bali which represents Ayu's residence. The Dvarapala statue, flower offerings, and the Balinese kite festival characterize the unique atmosphere of the island of Bali. If analyzed further, Bali Island is the choice of setting of this animated ad location because it represents the regional lifestyle in Indonesia which is still calm and beautiful. This is because Bali, despite being a tourist destination visited by tourists from abroad, can still maintain its local culture so that it becomes a special attraction 
for tourists. Therefore, Indonesia, besides being known as having Jakarta as its capital, is also known as Bali as a tourist area that is thick with Indonesia's local culture.

\section{b. Architecture}

The identity of Balinese culture in this advertisement animation was first shown through the first scene at the school gate. The school gate is filled with Balinese decoration. The decoration on the Balinese architectural gate has a symbolic meaning which also is used as a sign of building function and the position of the building owner (Suryada 2011), whereas the Balinese-style ornamental gates shown in this animation represent no special forms or motives that have any particular meaning behind it. It's just that from the material and shape used, it's enough to show the identity of typical Balinese architecture.

c. Properties

- Dvarapala Statue

According to Arina (2019), the Dvarapala statue consists of a pair of large muscular statues with bulging eyes, a large fanged smiling smile, and usually carries a mace in charge of guarding the temple gate. It has a philosophical and deep meaning behind it. This statue is believed to reflect human beings who will enter the sacred area and remind them to be introspective and clear their thoughts, actions, and words.

- Bali Kite Festival

The Bali Kite Festival is an international event that is held on an annual basis in Padang Galak, Sanur, Bali. There are various forms of kites shown in this event, such as fish (Bebean), birds (Janggan), and leaves (Pecukan). Usually, people fly and compete with traditional giant kites. This is wrapped by religious events with the intention of sending messages to Hindu gods so that they can bless them with abundant agricultural produce (Freidin 1989).

- Offerings

Offerings are offerings to Hindu deities, usually in the form of flowers or food. The offerings are placed in a container (such as a leaf or tray) and placed in a certain place. The Balinese have a belief that if they make their offerings they will be kept away from bad luck and will be blessed with safety and prosperity (Tracy 2016).

\subsection{Jakarta}

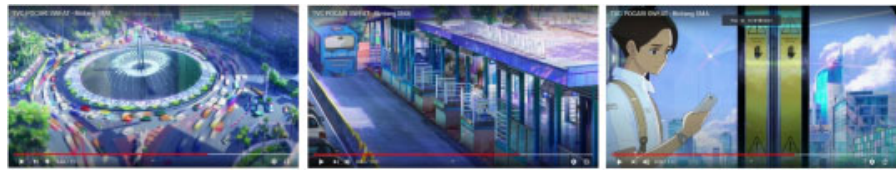

a Architecture

The location shows the hustle and bustle of the city of Jakarta such as the Bundaran HI and Bung Karno bus stop. This can immediately inform the audience that these two student residences have very different atmospheres. The frame that shows Jakarta's city landscape which is a metropolitan city can be seen from skyscrapers and the dense traffic conditions that are the face of Jakarta. One of the landscapes that became the icon of the city of Jakarta in this animation is the Selamat Datang Monument which is located right in the middle of the Bundaran HI or the Bundaran Hotel Indonesia and the Bung Karno Bus Stop. Besides that, the pen-shaped blue skyscraper clearly visible in the Reza scene inside the subway is Wisma 46, which is the second tallest building in Indonesia after Gama Tower (Wahyudewi 
2016). With its unique shape, Wisma 46 is one of Jakarta's most notable icons, besides the National Monument.

\section{CONCLUSION}

From the analysis provided here, it can be concluded that Indonesian culture is represented in the background of the Pocari Sweat advertisement "Bintang SMA" through the location, architecture, and property settings. The Indonesian culture presented in this animated advertisement is Balinese culture, which is thick with various decorations in the form of carvings both in architecture and property, such as the Dvarapala statue and events such as the kite festival and offerings. Meanwhile, the culture or lifestyle of Jakarta is conveyed through architecture such as skyscrapers like Wisma 46 and the Welcome Monument, as well as the congested traffic conditions at the HI Roundabout or the Hotel Indonesia Roundabout. The animated Pocari Sweat ad "High School Star" shows that cultural values are the main concept in their advertisements. In recent times, a brand will increasingly exist if it has strong ties to certain cultural values (Hendroyono 2019). Makoto Shinkai's beautiful visual style and detail are at the peak of his fame and are utilized in this animated advertisement which can attract buying interest from certain groups. This is also being developed in the world of advertising in this pandemic era, which is called "goodvertising". Besides, when viewed from the media selection in the form of animation, based on the results of the questionnaire, it can be concluded that animated advertisements are effective in promoting products and can be used as alternative advertising choices during the pandemic. Thus, it can be understood that making an advertisement is not only about persuasion and selling products or services, but also must pay attention to the situation and take advantage of opportunities, enabling the brand to survive through various situations.

\section{REFERENCES}

Afdjani, H. 2010. Makna Iklan Televisi (Studi Fenomenologi Pemirsa di Jakarta terhadap Iklan Televisi Minuman “ Kuku Bima Energi” Versi Kolam Susu. Jurnal Ilmu Komunikasi, (8)1:96.

Arina, M. 2019. Mengenal Dwarapala, Patung Penjaga Tempat Suci di Bali, Etnis, accessed July 10, 2020, < https://etnis.id/mengenal-dwarapala-patung-penjaga-tempat-suci-di-bali/>

Freidin, S. 1989. Return to Bali. Kite Lines, 7(3)31-35.

Hendroyono, H. 2019. Artisan Brand, kenapa Begitu Penting? Jakarta: PT Gramedia.

Kress, G. and Leeuwen T. V. 2006. Reading Images: The Grammar of Visual Design, Taylor and Francis Group, pp. 46-214, New York.

Kusumanto, D. 2019. Yoshitoshi Shinomiya Berbagi Cerita tentang Pembuatan TVC Pocari Sweat - Bintang SMA, Kaori Nusantara, October 25, 2019, https://www.kaorinusantara.or.id/newsline/138511/yoshitoshishinomiya-berbagi-cerita-tentang-pembuatan-tvc-pocari-sweat-bintang-sma.

Munggaran, G.A. 2019. Representasi Awan Cumulonimbus Pada Background Art Film Animasi Jepang. Prosiding Seminar Animasi dan Visual Media Digital. Jakarta, September 19, 2020.

Pattymahu, D. R. 2016. Gerbang Sebagai Pembentuk Identitas Kota Studi Kasus Koridor Jalan Trans Sulawesi Di Malalayang Manado, Daseng: Jurnal Arsitektur, 5(2,3): 68-82.

Pilihan Promosi yang Tepat dalam Masa Pandemi Covid-19, Jawa Pos, June 26, 2020, Accessed July $25,2020,<$ https://www.jawapos.com/ekonomi/26/06/2020/pilihan-promosi-yang-tepat-dalam-masapandemicovid-19/>

Pocari Sweat Bintang SMA. 2020. online video, accessed July 1, 2020, $<$ https://www.youtube.com/watch?v= DCfk7tc_KqE>

Suryada, I.G.A.B. 2011. Varian-varian Ornament di Bagian Atas Lubang Pintu Masuk Bangunan Gerbang Berlanggam. Jurnal Sulapa 3(1):17-28.

Tracy, M. 2016. Menginjak Sesajen di Bali Bisa Celaka?, Pegi Pegi, accessed 1 July 2020, < https://www.pegipegi.com/travel/menginjak-sesajen-di-bali-bisa-celaka/>

Wahyudewi, P. 2016. Ini Dia 10 Gedung Pencakar Langit Tertinggi di Indonesia, IDN Times, accessed August 20, 2020, < https://www.idntimes.com/hype/fun-fact/putri-wahyudewi/ini-dia-10-gedung-pencakar-langittertinggi-di-indonesia/10> 